\title{
III. Divine Retaliation
}

$\mathbf{I}$

Ever since the day in 1844 when the loose leaves written by Carl Linnæus under the heading Nemesis Divina were recovered and entrusted to the care of Upsala University Library, they have continued to cause surprise and interest. And the small volume, subsequently bound, with its 203 octavo leaves, still preserves much of its attraction as a treasury of the innermost thoughts of the great naturalist.

It is known that Linnæus wrote these pages in the course of a long period of time and kept them strictly secret. When he dedicated them to his son, the younger Linnæus, he added: "Perhaps many stories are incorrectly told. Listen carefully; say nothing, do not injure anybody's name or honour." This admonition has been reverently heeded up to our own day. Until now no complete edition of the manuscript, existed, only a selection, in itself commendable, published and annotated by Elias and Thore Magnus Fries under the title Carl von Linnés anteckningar öfver Nemesis Divina ('Carl Linnæus' notes concerning Nemesis Divina'). The selection first appeared on the occasion of the doctoral investiture in Upsala in 1848 . A second, enlarged and revised edition was published in 1878 .

Unfortunately it has been impossible to arrange the originally loose $\mathrm{Ne}$ mesis papers into a form which would allow us to form a clear idea of their origin and their real connection with Linnæus' biography. Only in isolated cases are we able to establish the terminus post quem. We must, however, assume that Linnæus' views and outlook developed and changed in the course of time, and that the differences between his early years, his maturity and his old age have left their traces. As far as we know, Linnæus began to display signs of senility comparatively early on; at least in the $1760 \mathrm{os}$. The major part of Nemesis Divina, the title page, and the dedication to the younger Linnæus, appear to have been written during this period. ${ }^{1}$

1 Arvid $\mathrm{Hj}$. Uggla treats of the origins of the ND-MSS. SLSA I967, p. 13-19; see further the new complete edition, Stockholm I 968, pp. I6 sqq. [Author's note in the proof.] 
Linnæus' Nemesis Divina has been the subject of many different interpretations which, in themselves, will not be discussed here. Our main concern will be the central problem of the notes: the belief in fate and the concept of retaliation. But these are in their turn dependent on Linnæus' conception of Nature and God, and, not least, on his views concerning the unity and continuity of the natural and the moral world order. Whatever the sources of his religious ideas, and whatever changes they may have undergone, Linnæus' religious attitude to the workings of nature remained unaltered. But Linnæus' religion such as we know it from his writings, particularly in his earlier years, was undogmatic, un-theological and more or less heterodox from the point of view of the Church. This may have been partly due to his general outlook, his manner of viewing things in accordance with the inner necessity of the processes of nature and character of divine justice. To Linnæus crime and punishment stood out as a necessary unit, which finds its expression in the judgement of divine fate; this is the nemesis doctrine in nuce. The appeal is never to punishments or rewards in a future existence. For Linnæus 'experience' was the decisive criterion: "If you do not believe because of S.S. (Scriptura Sacra), then believe in it because of Experience", he wrote in the versified dedication to "My only son" which follows after the title page of Nemesis Divina. ${ }^{1}$

Linnæus' approach is that of a Theologia experimentatis. He collects cases which he regards as divine retaliation in this life. In retaliation he traces the old judicial principle that the criminal act has to be answered in the same way as it had been committed. In retaliation he also recognizes the combination of the inexorable law of Nature with God's own justice. Nemesis Divina thus becomes $\mathscr{f}$ us Talionis.

In what follows I shall try to show, with a few typical examples, how Linnæus applies his outlook to his material. Let us begin with two cases culled from people in his home district. First, Måns in Sannaböke, in the parish of Stenbrohult in Småland.

"This happened during my childhood in my birthplace", says Linnæus. Måns was "a callous man, cruel to his father. Måns Månsson, the son, pulled his father by

${ }^{1} N D$, p. 3 (MS 2). 
the hair, and tried to drag him out of his cottage. When the father reached the door, he cried: 'Masse, don't drag me any further; I did not drag my father any further.' The son answered: 'Yes, by the death of Our Lord, if you dragged your father to the door, I shall drag you outside it.' "I

Another annotation from Stenbrohult tells about Jacob in Såanäs, "who was on bad terms with his wife"'.

"During the Christmas holiday (in my youth) when she was walking over the ice to Church, she fell through and, crying for help, she clung on to the edge of the ice for a long time, around a quarter of an hour. The husband who was standing on the bank, as it happened near the farm, said that he dare not walk on the ice, and furthermore he would be happy to be rid of her; she drowned. Five years later Jacob's fingers, with which he could have rescued his wife, began to rot away on both hands which subsequently caused his death."

It is natural that such stories should embody traditional expressions of the general indignation felt against the perpetrator of gross crimes committed against the Fourth and Fifth Commandments. But the stories are also traditional variants of such motifs as tend to be drastically or cruelly quoted for retaliatory purposes.

But Linnæus also gathers his observations from an older, more historic setting: this is the case with Charles XI and the story of Carl Piper and Jacob Boëthius. Of the former it is said:

"King Carl made a great many Noblemen homeless through the 'reduction" (his confiscation of castles and estates). When he was dead, the Royal Castle in Stockholm caught fire, and his body could only be rescued with a great deal of difficulty". 3

It is well known that Charles XI's severe reduction of the fiefs of the nobility for a long time afterwards made the King's memory hateful to the social classes most affected by it. That the episode of the Castle fire in I697 was included in the Nemesis material, may however, rather be ascribed to pity for defenceless and innocently suffering people. Direct comparisons suggest themselves among these notes. Of Dean Boëthius in Mora it is told that for political reasons he was arraigned by Carl Piper, the favourite of Charles XII, and that he was imprisoned for life in the fortress of Nöteborg.

\footnotetext{
$1 N D$, p. 5 I (MS $\mathrm{I} 18$ ).

${ }^{3} N D$, p. 44 (MS 192).

${ }^{2} N D$, pp. 50 sq. (MS 92).
} 
"The Russians conquered Nöteborg and were victorious at Pultava, where they captured Piper, released Boëthius from prison and sent him home to Sweden, and put Piper in the same prison where he perished wretchedly". ${ }^{1}$

The subjective explanation of Linnæus' choice of these examples is to be found in his reaction against the severe judgements of the absolute monarchy. Otherwise it is difficult to believe that the vengeful sentiments reflected in a given circle of people, with which Linnæus probably had been in contact, could bring about much more than a fictitious relation between crime and punishment.

The following case is also probably based on hearsay.

"Slichert, a yeoman of the Royal Guard, loved a widow von Byzen and gave her an estate. The brother-in-law resented this and one night he fired three shots through the window of the house. 'The bullets went straight into Slichert's stomach. Several years later the brother-in-law developed cancer in the stomach with three holes, which caused him a gruesome death." 2

The principle of similarity is, in the case of Slichert, developed in great detail, so that the punishment becomes a clear reflection of the crime. Such cases are not very frequent, but when they occur, the reader cannot but assume that they are based on hearsay and contain very little truth. In other cases the critical reader is compelled to assume that Linnæus deliberately looked for examples of this kind of notion. His inductive method thus becomes more apparent than real.

The case, however, is different in those cases which Linnæus came across in his contemporary environment. Here we encounter a long and variegated gallery of intriguers, receivers of bribes, swindlers and rascals in public service. The narrowly bourgeois and academic circles contribute numerous cases of greed, grudge, perfidy, loose living, quarrelling and favouritism. Linnæus describes his cases in such a frank and realistic manner that the retaliation sometimes sounds like an echo of vox vulgi.

It is said that the Upsala Alderman, Kyronius' crimes provoked a public cry, "Crucify". He had to leave everything he had "like a sparrow from the ears of corn,"' but escaped justice by fleeing the country. The Penal Code

${ }^{1} N D$, p. 3 I (MS I26).

$2 N D$, p. 53 (MS 66).

${ }^{3} N D$, pp. 37 sq. (MS I85). 
of Nemesis, however, is seldom so indulgent. In most cases retaliation inflicts itself in the form of illness, misfortune and poverty.

The case of Herkepæus is connected with Kyronius above mentioned. Herkepæus was Mayor of Upsala, and was accused by Kyronius of having made derogatory statements concerning the Four Estates of the Realm. He reminded his judge of the fact that he had once carried the latter's father out of a burning house, but in spite of this he received a severe sentence. Ten years later the judge's own family estate was burnt to ashes. ${ }^{1}$

The cases of ruthlessness and inhumanity are numerous. Greed, ill-gotten goods, or advantages acquired at another person's expense, informing, unjust accusations are in the same way subject to retaliation in the most summary fashion. Typical of the period is the notion that informing is revenged by informing. Moreover, when the denounced person takes his own life, it may so happen that the informer follows suit. ${ }^{2}$

The widowed second wife of the Upsala Professor Nils Wallerius is said to have been "extremely cruel to her step-children, servants, husband and children". When her husband died she parted from them under several pretexts. She lost the house through fire in 1766 , the cowhouse in September and in the December of the same year the vicarage to which she had moved; "she and her son barely managed to escape in their nightgowns". "Do not be cruel and ruthless. There is no grace for him who has no charity", adds Linnæus. ${ }^{3}$

Renhorn and Rogberg, who appeared as prosecutors and judges in the Brahe trial in 1756 , lost their health and died some time afterwards from "alteration". All the judges of the Goertz trial in 1720 meet with misfortune, and "the merriest of all dies of melancholy"."

Sometimes we sense a hint of Humor im Recht in Linnæus; as in the example of the merry judge, or when the two quarrelsome sisters Friesendorff of Hammarby finally have to share the same grave. ${ }^{6}$

In contrast with these cases is the homicide group (Swedish: mord and

\footnotetext{
$1 N D$, p. 35 (MS I90).

${ }^{2} N D$, p. 3 I (MS I25).

3 ND, p. 46 (MS 85).

${ }_{4} N D$, pp. 29 sq. (MS II2, II5).

${ }^{5} N D$, pp. 34 sq. (MS I48).

' $N D$, p. 52 (MS 142).
} 
dråp). Here the retaliation punishments predominate completely. In certain cases the retaliation reflects the detailed circumstances of the crime itself. The notorious and disastrous murder of Major Malcolm Sinclair in I739 was regarded by Linnæus as a divine retaliation for a similar crime committed by Sinclair who, during his captivity in Russia, had stabbed to death a Warrant Officer called Lod. However, in due time the instigator of the Sinclair murder and his accomplice were also hit by the divine vengeance. ${ }^{1}$ Another Nemesis story is about a young Count Cronhielm, who meets a peasant on the ice, runs into the latter's sledge, and in his anger beats the peasant to death. Some years later the Count goes through the ice in a rift at the same place. He cries: "I see God's vengeance in this place", and drowns." The most consistent retaliation is to be found in the case of Slichert referred to above. In such cases we find ourselves in the classical domaine of the lex talionis.

The notion that the divine vengeance can fall upon the descendants of the guilty, and that it can be brought about by another person than the wronged one, is closely related to the primitive belief in retaliation. Linnæus gives us several examples showing that no good will come of possessions acquired through ruthlessness against one's fellow men and meanness towards one's own self: such goods will not even outlast the next generation. The following typical example may provide an illustration:

"Sohlberg, a mining inspector in Falun, rich, fleeces the poor miners almost down to their bare bones and in this way he has amassed his fortune. He has five quick-witted sons, but none of them an economist. All poor and in debt. De male quæasitis non gaudebit tertius heres." 3

The same moral is expressed by an old Swedish proverb: "Ill-gotten goods are not inherited by the third generation." This is to all appearances a purely social maxim based on experience. It is, however, probable that Linnæus regarded the act itself as the retaliation of a moral guilt. The following case is illuminating in this respect:

"Olof Håkansson, a farmer from Blekinge, Speaker at all the Parliamentary sessions, except one, from 1739 to I770. Amassed an unbelievable fortune, many barrels of

$1 N D$, p. 55 (MS I6r). Cf. pp. 43, 54 (MS I02).

$2 N D$, pp. 33 sq. (MS 162 ).

${ }^{3} N D$, p. 45 (MS 67). 
gold, took bribes; the wealthiest farmer living in Sweden, died in Parliament in 1769. Six months later in February 1770 his youngest son died, and then his daughter also of a ravaging fever. The son in Stockholm does not appear to be strong..."

Linnæus identifies the system of Nature with the moral system of the world, and equates physical and moral affliction. "The sons of great men become incompetent" (heroum filii noxx), is often quoted by Linnæus. "The unhappy are born to unhappy parents." 2

When retaliation thus becomes purely numinous, the retaliatory principle naturally looses its judicial meaning. This applies to the retaliation in many uncertain cases. When punishing abuses of the word of God, or breaches of oaths and promises, the retaliation is according to the Law of Moses. The case of Daniel Solander, Professor of Law, may be regarded as highly representative of Linnæus' views.

"Solander had been engaged to the daughter of Professor Hermansson, on whose
recommendation he had been given his position. After his appointment in I740,
however, he married the wealthy widow of a chemist. In the course of the years she
took to drink, squandered her fortune, and ruined the lives of husband and children."s

In the case of sexual delinquents it is often the physician in Linnæus that prevails. His attitude is pronounced only in connection with breach of faith in love and marriage. ${ }^{4}$ As for offences against property rights, Linnæus appears chiefly concerned with crimes causing permanent and irreparable damage to private or public welfare. ${ }^{5}$ Such divergences from more rigorous conceptions are worth noting, ${ }^{6}$ and they may also reflect a contemporary shift of opinion in legal matters.

The moral and judicial conceptions expressed in the majority of cases have a typically individualistic stamp. The talio rule applies to the culprit's descendants chiefly in such cases where hereditary and social circumstances are presumed to stand in a causal connection which is hidden to the world. The social structure and the development of the sense of justice stood in the

${ }^{1} N D$, p. 35 (MS I69).

${ }^{2} N D$, p. 20 (MS 28).

${ }^{3} N D$, p. 6I (MS 7I).

${ }^{4} N D$, pp. 59 sqq.

5 ND, p. 23.

${ }^{6}$ Similar views already expressed in $D N$. 
way of belief in a retaliation of a more far-reaching character. In this respect there is a marked difference between Nemesis Divina and a doctrine of retaliation which regarded punishment sub specie aeternitatis, and consequently tried to apply it in maximal forms even in this world. Temporal and eternal death are never identified by Linnæus. His Nemesis has no field of action outside our temporal existence. But nevertheless his doctrine of retaliation has an immanent function in social and historical events.

According to Linnæus no one can create his own happiness, although he can contribute to his own misfortunes. Only the Devil can blazon abroad that everybody is the maker of his own fortune since in that case he would be his own maker (causa suæ existentix). Linnæus' views are in keeping with his Stoicism. But at the same time they tie up with the Theodicy problem of the period. The great earthquake in Lisbon on All Saints' Day, Ist November, I755, had roused the educated classes of Europe out of the illusion of "the best of all possible worlds". Even Voltaire began to entertain pessimistic doubts that things were perhaps not so good after all. ${ }^{1}$ This terrible catastrophe provoked Linnæus to a meditation on the "wickedness" of the world. Lisbon was ravaged by "earthquake, floods, accidental fire and all the cruel punishments imposed by God on obdurate sinners; half the earth quaked, and by this He revealed that He could hear, and have mercy upon the unfortunate even if they were heretics." Linnæus refers here to the stakes of the Catholic Inquisition which were lit in Lisbon on All Saints' Day. ${ }^{2}$ Like Voltaire, Linnæus aims at L'infâme, the Catholic Church. But while the former makes allowance for the future, Linnæus' pessimism is radical in its anchorage in retaliation by fate. Linnæus' diatribe against Catholicism in the Nemesis deserves to be mentioned in this connection because it appears to be directed mainly at the abuses of religious faith. This is shown by an appropriate example about the mine of Norberg in Dalecarlia, which was flooded because all work had to cease during a Religious Holiday. ${ }^{3}$

The Nemesis doctrine cannot claim to be a revealed faith. It claims to be based on experience, and this is conditioned by the contemporary social

1 Cf. Ernst Cassirer, Die Philosophie der Aufklärung, pp. I96 sq.

${ }^{2} N D$, p. ${ }_{3}$ (MS 56 ).

${ }^{3} N D$, pp. 16 sq. (MS 4,9 ). 
situation. The social sanction is salient in such cases where crimes accumulate; a case in point being the story of Kyronius. Misfortunes never come alone, Linnæus says with a proverbial expression. Public opinion pushes the chariot of the divine vengeance: vox populi, vox dei. Retaliation thus appeals to the desire to "crucify" of popular justice. Duelling as a form of private vengeance is not morally sanctioned by Linnæus. Not only does the duel fall outside Linnæus' code of honour; it is also contrary to his religious outlook. "Everyone wants to be God, everyone wants to pass capital sentence on his neighbour by sword or pistol. Alas, poor fool, your time is nevertheless running out." Here the motive is not, any more than in the other cases, taken into account. No guilt is attached to the one who is slain. The killer is punished afterwards, after the act has been committed.

When Linnæus introduces historical persons and events into the Nemesis notes, it would seem as if he had ultimately wished to give the judgements of fate a place in the pages of history. This is the impression one gets when he classifies the Roman emperors according to their political actions and length of life. Linnæus may indeed have aimed at something in the way of a philosophy of history. But this, of course, could never be more than an experiment with uncertain facts, which he was unable to bring into a pragmatic order. His methods were inadequate for such tasks. There is nonetheless a curious and interesting trend of thought in his reasoning of retributive fate, a trend which nowadays may perhaps be recognized in Spengler and Toynbee. 
The concept of fate is to be found already in the later parts of Diæta naturalis:

Comœediam ludunt Clotho, Lachesis, Atropos.

Fortuna comødiam agit. ${ }^{1}$

We come across Lachesis for the first time here in a Linnean context. This was to be the symbolic title of Linnæus' Dietetic. We also read here the following invocation to Omnipotent Fate. The English translation can only give an imperfect idea of the Swedish original.

O Fate, cruel tyranny. Have you alone received power over all that God has created to His own praise; are you to be allowed to make His entire masterpiece of no avail, you alone to make confusion in the whole world?

You take away the old and wise, and leave the young and imprudent. You put out the sparkling eyes of this world and you spare the blear-eyed. You throw away the rich who have built themselves up, you do not hear the cries of the poor.

You take away the work from the one who builds before it is finished.

When we have toiled for a long time in misery, and begin to find rest from our toil, you take the opportunity to end the pleasure before it starts.

The misery of the poor does not move you, nor is the power of the mighty spared. No intellect can escape you and no quality avoid you.

No place in the world is safe from you. ${ }^{2}$

The concept of fate recurs again in the Prolegomena of Lachesis naturalis. But there it is no longer contrasted with the concept of God as earlier. The two views are separated in time. ${ }^{3}$ In the Lachesis it is no longer a question of fatum but of fata. It is stated there that the fates are the "hands of God," and "follow their own irrevocable course"; "they happen just as it has once been decided". ${ }^{4}$

\footnotetext{
${ }^{1} D N$, pp. 202 sq.

${ }^{2} D N$, p. 204.

3 'The introductory part of Lachesis verisimilarly dates from the $1760^{\prime}$ 's.

${ }^{4} L N$, pp. 9 sq
} 
In my opinion we are in this case dealing with the opposite concepts of

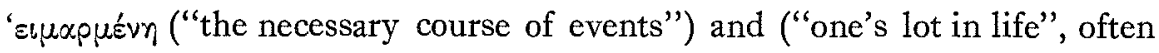
in the plural, fata), in the last resort determined by the Deity himself. In the present case a difference between Linnæus' earlier and later views is thus accentuated.

In Lachesis it is difficult to find any attempt to reconcile the concept of fate with the question of the freedom of human actions. Nature is said to "force the will" (cogit velle), ${ }^{1}$ but the context shows that Linnæus wishes to say that this happens through desires, pains, emotions and sensations of hunger. The passage deals with physical expression only, and thus lacks metaphysical significance. In Nemesis on the other hand, Linnæus considers the moral aspect, and indicates his attitude by saying that any man can hang himself, drown himself, or cut his throat; he is also free to choose not to do so. But if, for some reason, he is sentenced to death by the Highest Judge, he is not free to escape from his sentence, but his death follows inevitably. ${ }^{2}$ Thus, man is free to commit a crime or to decline, but once the crime is committed, he cannot escape his punishment. The problem of free will is thus only apparently eliminated in this highly sophistical argumentation.

When attempting to resolve the old problem of the "philosophers", Linnæus is thus unable to overcome the indecision between determinism and indeterminism, which was characteristic of the intellectual milieu of that time. His deterministic outlook leads him to a formalistic view on the "justice of nature", which, according to a strict principle of Talion, takes into account the act only, and not its motive. If one disregards the fact that God, according to Linnæus, acts as Nature's retaliating agent, this doctrine of punishment outwardly resembles Kant's moral theory. The eighteenth century moral philosophers often tended to equate the order of Nature and the moral world order. On the one hand they emphasize the Stoic conceptions of duty, and on the other, they tend to let the order of Nature and the moral world order merge into irrationalism. Both these features are to be found in Linnæus' conception of Divine Retaliation.

Already in the Dirta naturalis we find suggestions of the Nemesis concept. Man sins against God through ingratitude towards him, through indiffer-

$1 L N$, p. $2 \mathrm{r}$.

$2 N D$, p. 2 I (MS I4). 
ence (securitas) to the punishment which threatens. Man harms his neighbour through malice (malitiositas), ruthlessness and partiality (suppressio). The peasantry and subordinates are reduced to poverty; of which "so many become destitute, which causes no concern although half the multitude starve to death". We observe that the young Linnæus is intensely indignant towards ruthlessness, encroachment, and injustices committed against subordinates and the poor. Justice occupies the central position in his ethics. We have duties towards God, towards our neighbour and towards ourselves (in Deum, proximum, in se ipsum), and we are punished in this life if we infringe upon them. "God is a just judge." "I can never believe that so just a God spares the sinners." Tandem justa causa triumphat. ${ }^{1}$

This strong sense of social justice is repeated in almost the same words in Nemesis Divina. From the passage on poverty we quote the following remarks: "Think of the poor slave, who works for you while you sleep. He plows the field, and you reap. You say: this is my estate, I can do as I please. I say: nothing is yours; God has lent you everything." 2 In the same way it is said of wealth: "All we have is borrowed from God. We bring nothing with us; nor do we take anything away. When God and Fate, which is God's executor, take it away, we grieve for having lost what belongs to us; this has not been ours, it has only been a loan." One should be careful not to commit injustices against the powerful and poor; weapons are left with those who have been plundered. "They call upon God."3 A great many cases of ruthlessness and inhuman dealings are included in the Nemesis collection.

Nemesis Divina may, with some dramatization, be called a funeral offering on the altar of Linnæus' sense of justice occasioned by the blood-guilt of the executions in Stockholm on 23rd July, 1756 , the day when the participants in Queen Louisa Ulrica's abortive coup d'état met with a horrible death. In the Lachesis notes probably dating from later years, Linnæus mentions this harrowing experience:

"I saw no one as cruel as a human being, and shuddered at the thought of Stockholm's Butcher's Bench."

\footnotetext{
${ }^{1} D N$, pp. 193 sq.

$2 D N$, p. 195 .

${ }^{3} N D$, p. Io (MS 45).
} 
"I saw miserable death surprise the most powerful, wisest, bravest, thus is this a most horrible world, a laniena and rapina crudelis."

In Nemesis these events are referred to in general terms. The retaliation does not only befall the guilty but also their judges. ${ }^{2}$ To these annotations Linnæus also adds accounts of earlier bloody sentences; among other the execution of the Generals Buddenbrock and Lewenhaupt after the RussianSwedish war $\mathrm{I} 74 \mathrm{I}-\mathrm{I} 742 .^{3}$

On the back of the title page of Nemesis there is a quotation by the old Roman poet Claudianus:

Sæpe mihi dubiam traxit sententia mentem, Curarent Superi terras: an ullus inesset

Rector aut incerto fluerent mortalia casu?

Abstulit hunc tandem Rufini poena tumultum, Absolvitque Deos. ${ }^{4}$

One cannot help thinking that when Linnæus quoted the verses on the fate of the East Roman Statesman, he had in mind Count Erik Brahe who had been executed in $\mathrm{I} 756$. But at the same time the words suggest a religious resignation to divine retaliation. Something similar is to be found in the notes on the Brahe case.

In a communication to Svenska Linnésällskapet in Uppsala in I940 Dr. Arvid $\mathrm{Hj}$. Uggla emphasized that these Nemesis notes are datable to the $\mathrm{I} 760 \mathrm{os}$. Linnæus' reflections on the retaliating justice laid down by Providence in Nature's own legislation, assumed a specific direction and a definite character after the afore-said historical events. There is no denying that Nemesis Divina forms, to a great extent, Linnæus' personal way of squaring accounts with the private and public morals in the so-called Period of Liberty. Linnæus' attitudes were like those of many of his contemporaries, principally determined by a morality which ties the individual to his own deed.

The concept of Nemesis in every case appears to have attained its main shape in the 1760 . It was also probably during this period that Linnæus

1 LN-MSS, fol. 2 r.

${ }^{2} N D$, p. 3i (MS г 22).

${ }^{3} N D$, p. 3 I sq. (MS I27). Cf. p. 29 (MS I Io sq).

$4 N D$, p. I8 (Ms I) 
committed to paper the majority of annotations on Nemesis Divina. In any case by this time the Nemesis doctrine received distinct elements of the Talion of Moral theology. It is scarcely a coincidence that the title page of the notes was designed at the same time as there appeared in a Swedish translation in 1763 a treatise by the Dane, J. C. Friess, called Den gudomliga vedergällningsrätten ('The Divine Justice of Retaliation'). This is also shown in the definition under the title Talio est xqualis retributio, unde reciproca talio, Autopathia Graecis. The definition comes straight from Friess, who in his turn, had borrowed it from P. Ravenel's Bibliotheca Sacra which was published in Geneva in I600. On the back of Linnæus' title leaf there is a direct reference to Friess, where it is briefly stated that Linnæus had "a little from this". On closer inspection this proves to consist of some ten annotations.

Among these there is a Rabbinical legend, which Linnæus quotes both in Lachesis and Nemesis. ${ }^{1}$ The legend tells us how Our Lord showed Moses on Mount Sinai, how the Divine Retaliation demands a life for a life, uses the culprit as an instrument, and rewards the innocent sufferer. There is no doubt that this story tallies with Linnæus' outlook. But it is far from certain how far the influence of moral theology prompted Linnæus' ideas of retaliation in the direction of Old Testament justice. It is more likely that Linnæus' idea of retaliating justice had already begun to take shape in his home milieu during his early years.

At the beginning of the eighteenth century the general view on legal matters had not undergone any important changes since the preceding century, during which the Calvinist inspired penal principles of Charles IX had been accepted as a guide for the judicial system. All crimes regarded as violations of the Law of The Lord were to be dealt with according to the Old Jewish Penal Code. Capital punishment was therefore applied to the widest possible extent. Most forms of serious crimes, such as homicide, incest, blasphemy, ingratitude to parents, damage to the welfare of another person, and injuries to helpless creatures, are enumerated in the Nemesis list of objects of divine retaliation.

${ }^{1} N D$, pp. 22 sq. (MS 27), LN-MSS, fol. $8^{\text {r }}$. Cf. Louis Ginzberg, The Legends of the Jews, III, 4 impr., Philadelphia r954, pp. I35 sq. 
Linnæus does not, however, choose Biblical examples, but collects cases which he regards as representative of experience. The Canonical books and the Apocrypha of the Old Testament are, in the same way as the writings of the Roman Stoics, quoted in order to convey proverbial truths. The Proverbs of Solomon, the pessimism of the Ecclesiastes, and the wise words of Ecclesiasticus was part of the cultural heritage and the popular tradition of the period. But Linnæus' Nemesis doctrine is principally based on different foundations. The material consists of a collection of experiences, stories, reminiscences and products of his reading, but the theoretical aspects applied to these alleged facts are, in many respects, those of Linnæus' own time. It should be kept in mind that the concordance of Biblical and Stoical quotations also is an outcome of comparative tendencies; a fact from which, of course, very few historical conclusions can be drawn.

Seen objectively the conception of the penal application of retaliating justice was considered important during the middle of the eighteenth century. In this respect there is an obvious difference between the seventeenth century confusion of the Divine and the Civil Penal Code, and the eighteenth century's advance towards a more secularized jurisdiction, which Linnæus could not ignore. The humanization of Swedish Law had commenced at the end of the seventeenth century. But it progressed slowly, and the definite impact was not felt until the reign of Gustavus III. But Linnæus' sense of justice reacted, as we have seen, against acts of ruthlessness, cruelty and violence. His sympathy with poverty, destitution and abandonment is movingly expressed in Nemesis Divina. His own administration of justice while Rector of Upsala University proves his humane views on law and justice. The author of Nemesis does not revert to the Old Testament Retaliation which was during Charles IX's reign: "a soul for a soul, an eye for an eye, a tooth for a tooth, a hand for a hand, a foot for a foot". Retaliating justice is administered according to the severe laws of nature itself. But for Linnæus God is an enlightened ruler. This tendency was not unfamiliar to a period when Frederick II of Prussia's sister was the Queen of Sweden, and Gustavus III was heir to the throne. Nemesis Divina displays, as we have seen, many signs of the gradual modification of the concept of retaliation.

On the other hand, we should not forget that Linnæus was influenced by a neo-Hippocratic conception of human life. Even the later part of Diæta 
naturalis contains a passage on a moral dixta divina, which, with reference to the teachings of the Bible and the Stoics, gives expression to those same rules of life which we find exemplified on many later occasions. ${ }^{1}$ The very headings indicate the outlines of this doctrine: tranquillity, freedom from dejection and anxiety, envy, greed, voracity, violation and fornication. The general maxim proposed by Linnæus is: to live a blameless life (innocentia vitx). We have here, then, purely Stoical virtues in a christianized paraphrase, and they all find expression in the Nemesis Divina.

The retributive justice of the Nemesis punishes such acts of commission and omission that have escaped punishment, or else been committed in secret. The Law of Nemesis is the Decalogue of Exodus (20: 3, 5-8, 12-17), but Linnæus gives the Ten Commandments his own rather deistically coloured formulation:

I. Through Nature and experience be convinced that there is a God.

2. Never make God witness an unrighteous deed.

3. Regard God's aims of Creation.

4. Do not be ungrateful.

5. Be careful of manslaughter.

6. Do not shame the women-folk and do not steal the men's hearts.

7. Do not accept any gain which has been made by foul means.

8. Be honest.

9. Do not conspire to overthrow others.

Io. Do not intrigue for thine own advantage. ${ }^{2}$

At some points the Commandments have been rendered with great freedom, and at others the deviations from the Canonical text show traces of Linnæus' own convictions. The wording also differs from the text of the Bible in its partly positive, and partly generalized form. The Divine Law of Linnæus only considers the complete act, and thus gives expression principally to a secularized justice in accordance with the law of Nature. Its numinous character is, however, disguised in the form of a divine fate.

\footnotetext{
$1 D N$, pp. I97 sq.

"ND, pp. 8 sq. (MS 58 ); on a rewritten leaf of Nemesis Divina the "Law" appears in a latinized version: I. agnoscas Deum universi; 2. non contemnes contumeliosa; 3 . videas Te factum in ejus gloriam; 4. gratus esto erga beneficia; 5 . non noceas ulli; 6. non habeas polygama; 7. non capias alterius, sinas suum cuique; 8 . non testem vocas cæcum Deum; 9. non sub prætextu aliena vindices. SLSA XXXIX, p. 63.
} 
The primary sources of the Nemesis Divina are partly unknown to us. But it is possible to form some idea of the religious emanation of the sources. Linnæus never tired of repeating: Numen adest. "Nemesis sees and hears everything. Let us tread carefully and not roughhew our way through the world", ${ }^{1}$ lest fate should hear us. Fate watches and listens, and demands of us moderation and discretion in words and manners. Words and wishes are uttered, promises and oaths are given, and like blasphemies and curses they may fall back on their originators with the whole weight of the power of the words. Envy, oaths and heedless words are regarded as magically working forces: all according to the magic law of retaliation. In this way popular belief, too, regards human behaviour; the difference is scarcely more than the breadth of a hand, yet it is worth noticing.

According to the Nemesis anxiety is, as such, fated, independent of sin and guilt. "Fear comes before danger", is an old proverb. Linnæus writes: "Charles XII believed that every bullet had its billet, went between them like hail. Whilst other frightened ones fell."' Linnæus also tells us about a cuckoo which he saw in Orsa in I734; the bird "shook and felt sick" before it was shot. He says that those who worry when they go to war or lie sick in bed hardly escape alive. ${ }^{3}$ Both in the Nemesis and the Lachesis there is the story of Petrus Löflingt who stumbled whilst he was saying his farewells before the journey which ended so tragically in Guiana in $175^{6}$. A similar thing happened to Peter Forskåhl, who met his fate in Arabia in 1763 . At this point Linnæus notes Ovid, and also mentions a current phrase of his own time: "His farewell shot misfired, he will not return."' A person who does not fear infection, remains uninfected. Fear is both a sign of fate and a natural cause; this idea is highly typical of Linnæus. He also emphasizes that committed crimes can never escape Nemesis in the future. Fate is divinatory; it makes itself known through omens and dreams. The sympathetic connection between crime and punishment, which is implied in the Nemesis belief, may become prognosticative as a sign of cause and effect. In this mysticism

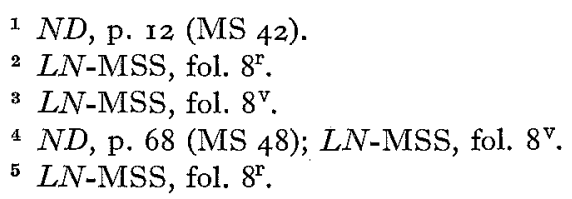


of fate magical and religious elements merge. One thing should, however, be borne in mind: Linnæus' conception of the phenomena, with which he dealt, falls within his explanation of nature, regardless of whether it is interpreted as natural religion or natural magic. For this reason the art of divination outside these boundaries does not appeal to him. He dismisses the art of divination and "planet reading" by asking sceptically whether that sort of thing can be of any value. ${ }^{1}$ But he does not say, like Horace: nefas est.

The retaliatory indignation against the criminal brings together justice and religion. From the religious point of view the sinner is punished by the act of sinning, and the crime revenges itself. When the crime is regarded as sin and guilt, human misfortunes are often seen as divine punishments. Crime and punishment are linked together in this way in a sympathetic union. The retaliation is regarded as a force which, operating of necessity, is released in certain situations. The retaliation becomes an avenger of fate, which comes into operation according to religio-magical or juridical-moral principles which may co-operate or work against each other. Sin and crime are frequently identified as guilt, and regarded as the material cause of the punishment.

No real equivalence can reasonably exist between them. The retaliation often becomes a legal fiction, Nemesis only a fictitious Dike. The restrictive rules of the Talion become obscured by the numinous belief in fate. The sympathetic connection between crime and punishment is regarded as a symbolic similarity, and in the last resort becomes fictitious. Neither human nor divine justice can work without norms. It is this feature which makes the border-line between jus naturæ and jus divinum so extremely arbitrary.

${ }^{3} L N$-MSS, fol. 8. 
Linnæus' personal attitude is coloured by the virtues of Stoic ethics, honesty, duty, and justice. These ideals determine the notion that infringements of the moral laws are avenged in this life by the Divine Order of Nature. "Fear of God, diligence, orderliness, virtuousness, helpfulness and that Emperor's Crown: honesty," are the qualities which Linnæus praises in his late friend, Andreas Neander. ${ }^{1}$ There is no mention of rewards and punishments in a future life. The positive components of this ethical ideal culminate in the

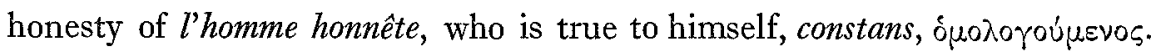
This was the Stoic life-ideal as formulated in the seventeenth century by Justus Lipsius, du Vair, and, a little later, by Descartes. ${ }^{2}$ This was something which Linnæus could hardly avoid coming into contact with during his period in Holland in the I730s. The individualism of this conception of life is obvious, and with some modification one may call this Stoicism, as did Descartes, a moral for melancholics. Both these features suited Linnæus' character fairly well. He frequently quotes the writings of the Roman Stoics, in particular Seneca. Sometimes he does this in order to gain support from the classical authors, but almost equally often the quotations are made to convey nuances of his own line of reasoning. It would be very rash to conclude that Linnæus derived his opinions from ancient Rome, on the contrary his Stoicism displays many positively contemporary features. It should also be borne in mind that many of Linnæus' contemporaries, such as Anders Johan von Höpken, were adherents to the same ethical doctrine.

It has been argued that Linnæus' speeches on virtue and happiness contain downright classical features. The most personal expression of this influence is to be found in the above-mentioned funeral oration in memory of Neander, "whom fortune had hated and virtue defended". ${ }^{3}$ Here we recognize the

\footnotetext{
1 SLSA I925, p. 94.

2 Ernst Cassirer, Descartes, Stockholm 1937, pp. I04 sqq.

${ }^{3}$ About Andreas Neander (I7I4-I765) see Th. M. Fries, Linné, II, pp. 285 sq.; Erland Ehnmark, Dygden och Lyckan, SLSA XXVII, I944, pp. 8I sqq.
} 
problem posed by Cicero and post-classical Stoicism. The fact that Linnæus also gives Virtue and Fortune a rather animistic concreteness reminiscent of theological speculation and medieval popular religion need not, however, detain us here. ${ }^{1}$

Virtue is the one firm ground of action. It is crowned by honesty and integrity in human conduct. Success and fortune become evil when they produce or promote evil. But fortune is a transitory and undeserved gain, even when accorded by God. Virtue itself easily becomes negative, if it is made the opposite of happiness. The pessimism of this conclusion thus becomes obvious, and the pessimistic strain in Linnæus' conception of Nature and ethics shines through the whole argument.

The retaliatory indignation in Linnæus' reactions to crime and guilt almost completely predominates over the retributive approval towards good deeds. In the entire Nemesis Divina there is, as Fries early pointed out, not more than one single clear example of the latter. This is less surprising when one considers that Nemesis is primarily a record of crimes. But this circumstance is fully explained only when we take into account Linnæus' pessimistic view of the course of nature as bella omnium contra omnes. "Life is lamentable", Linnæus exclaims in the same passage of the Prolegomena of Lachesis. ${ }^{2}$ One is almost tempted to recognize such expressions as an echo of Hobbes, but one can also trace similar statements by Rousseau concerning a social condition under which, as Linnæus says, one man oppresses another, and does not live as his fellow man, and does not speak to him as his equal. Peasants and servants are robbed of their belongings, which are given away to others, and may become destitute, regardless of whether the majority of people are starving to death. ${ }^{3}$

These reflections show that the general problem of an equilibrium between good and evil was becoming as secularized for the young Linnæus as for Jean Jacques Rousseau. The crux of the period was how the wise rule of God was to be reconciled with such a world. And as the Theodicy question became more secular, the principle of justice emerged with growing distinct-

${ }^{2} N D$, p. 12 (MS 42$)$.

${ }^{2} L N$, p. 6.

${ }^{3} D N$, p. I94. 
ness; this was the case with Rousseau as well as with Linnæus. ${ }^{1}$ It was in this mental milieu that Linnæus' idea of retaliation in this life took form. Three features characterize his way of thinking: the divine retaliation, the inevitability, and completion in this life of the retaliation, quite independent of a future existence.

In Linnæus' notes we come across many philosophical fragments derived from post-classical Stoicism, from the pioneers of empiricism, Bacon and Locke, from Descartes until the early Enlightenment. Undeniable influences from the physico-theological speculations of Christian Wolff have often been traced in the later writings of Linnæus. The question of external influence is, however, too complex to allow a simple solution, and the influences have indeed been overestimated. It is uncertain whether Linnæus ever attempted to state these problems more precisely, and whether posterity will be capable of doing so is even more uncertain; such speculations will therefore be avoided here as far as possible. Concerning the philosophical structure of Linnæus' idea of retaliation it would appear, from what we know of its author, to point in a reasonably clear and distinct direction within his practical philosophy. For him, as for many of his contemporaries, it appeared natural to identify the order of Nature with the moral order. It was a notion with a timehonoured tradition from antiquity. This idea entailed that the moral law was thought to have been implanted in human nature; and in combination with human nature was considered to represent a divine law of human conduct. It was apparently in accordance with this principle that Linnæus applied his ideas of human and divine justice to his theory of retaliation.

This theory could well balance between predestination and determination in this life. At times it seems doubtful from which level it should be interpreted. There is always some ambiguity in Linnæus' words when he speaks about metaphysics. The orthodox theologians blamed him for mixing up God and Nature. After his stay in the Netherlands his religious attitude, at all events, seems to have been quite undogmatic and in some respects inclined towards heterodoxy. In the Lachesis-MSS Linnæus presents his Natural theology as follows:

1 Ernst Cassirer, Die Philosophie der Aufklärung, Tübingen I932, pp. 209 sq. 
Nature does not regard Christ as the Saviour and God, nor as a God manifesting Himself from the Holy Ghost, Father and Son, an immaterial Soul, nor as the Resurrection of the flesh. ${ }^{1}$

This can hardly be comprehended in any other way than that Linnæus' religion of Nature paid little attention to the dogmas of the Church concerning the Divinity, Christ, the Trinity, or the immaterial nature of the Soul and the Resurrection. Among Linnæus' numerous aphoristically formulated utterances we can find the following, which may be regarded as an explanation of the declaration cited above:

God has shown himself in nature, de quo dubitare nequeo.

In the revelation differently, in hinc hæsitavi.

I did not see the revelation through Nature.

I was neither duped nor deceived.

Oh, poor people, how they are beguiled by imagination. ${ }^{2}$

Linnæus' personal position is perhaps best described in his own words:

Non credo Deum me creasse sed scio; quo pauciores enim articuli fidei eo melius. ${ }^{3}$

We have no reason to doubt that he ever essentially renounced such a position. But it seems possible that during his later years he modified it from the direction of a primitive monism towards more dualistic ways of thinking.

In Diæta and Nemesis the eternal penalties are never mentioned. In the Prolegomena to Lachesis Linnæus sums up his own understanding of the connection between body and soul in a way, which to a certain extent brings to mind Malebranche's occasionalistic theory. Such a tendency is also regarded by Boerhaave. ${ }^{4}$ Some of these sentences seem worthy of rendering here:

Nature and the soul are inseparable companions, two in one.

The soul is situated between the cerebellum and the extended marrow.

The inner man has two sides; one governs the cerebellum and sets the will in

1 In the original: "Naturen ser icke Christum salvatorem et deum $S$ (ancto) $S($ piritu) et Patre et filio exeuntem deum, Animam immaterialem, resurrectionem carnis." $L N$ MSS, Theologia, fol. I $8^{r}$.

${ }^{2} D N$, p. I9I.

${ }^{3} L N$, pp. 23 sq.

4 Cf. B. P. M. Schulte, Hermanni Boerhaave Prælectiones de morbis nervorum I730I735. Een medisch-historisch studie, Leiden 1959, pp. $3^{85}$ sq. Cf. p. 404. 
motion, the other belongs to the extended marrow, apprehends and drives involuntary things.

The Soul and Nature often co-operate; often they fight each other; still more often they work separately. ${ }^{1}$

The word 'soul' is repeatedly used by Linnæus in its Latin form anima, and is regarded as a particula divinæ auræ.

So far as one can see, the sayings conform with Linnæus' philosophy of Nature. Linnæus regards anima as a material substance in accordance with ancient and later doctrines. With this point of view in mind one is inclined to believe that Linnæus renounced the ideas concerning the immortality of the soul. Several years ago the late Professor Erland Ehnmark of Lund urged such ideas. ${ }^{2}$ It is likely that he was in the right. But when he deduces these ideas of Linnæus directly from the Roman Stoics, I think that he goes astray. When we remember how ambiguously the conception of the soul is conceived in the philosophy of more modern times, the Stoical interpretation in this, as in other instances, is too far-fetched.

An overwhelming problem at the end of the seventeenth and the beginning of the eighteenth centuries was the theodicy, primarily formulated in the philosophy of Leibnitz but taken over in many varying shapes in the spirit of the following period. With any pretensions of certainty at any rate, it is hard to state Linnæus' position in this respect. His disposition, his experience, and his view of life could seldom consent to regard our world as the best of all possible worlds. A pessimistic streak in Linnæus' thoughts is clearly shown during the later years of his life. His Nemesis Divina has sometimes been called a theodicy; if so, it would be an inverted theodicy.

In his comprehensive biography of Linnæus, Bishop Elis Malmeström tried to interpret Linnæus' thoughts and words in terms of the physicotheological philosophizing in Sweden in the 1740 os and 1750 s. Doubtless Malmeström is right in finding reflections of it in Linnæus' writings and statements from this period of his life. But the conclusions in this direction are scarcely sufficient to allow us to form a general opinion on Linnæus' ways of thinking throughout his life. To try to trace any profound influences from

\footnotetext{
1 See Introduction, p. 20.

${ }^{2}$ Erland Ehnmark, Linnæus and the Problem of Immortality. Humanistiska Vetenskapssamfundets $i$ Lund Arsberättelse I95I-52, IV, pp. 63 sqq.
} 
his countryside home in the thinking of the mature Linnæus would also be to labour in vain. At any rate such impressions are very scanty and of quite another kind. Hints of Old Lutheran ways of thinking appear to be totally lacking. Substantially very little is to be gleaned from terms such as "natural theology" and similar terms. It is well known that the Wolffian ways of thinking were infiltrated into the theological learning in Sweden in the middle of the eighteenth century. But this says nothing about Linnæus' attitude towards religion and even less about his religious outlook throughout his life.

In reality, everything that raised Linnæus' wonder and curiosity con-

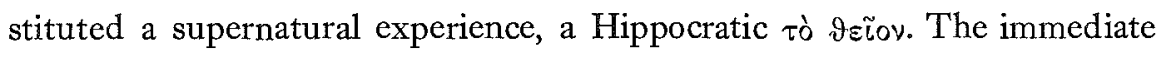
feeling revealed in this exclamation was the basic foundation of the religion that Linnæus had learned from the three realms of Nature. This naive feeling was expressed in cosmic visions, hymns to the Creator and thanksgivings to the Almighty. In the manner of the modern Stoics he sublimated his religious feelings in the "foremost of all passions", the admiration of God's created works. It was equally natural for him to think that God had created Nature for the sake of Mankind, and had appointed Linnæus as its High Priest. The reason for this outlook could have many causes. Stoicism was equally familiar with such ideas concerning meaning and election as St. Augustine and other teachers of Western civilization. The problem of an omnipotent and righteous God was actualized by many inner and outer circumstances in Linnæus' own life. It opened the gulf between good and bad, the result of which was that the antithesis of crime and penance could be bridged only by a Divine retribution in the temporal existence. The contrast between spirit and flesh, expressed in the Epistles of St. Paul which Linnæus quotes, opens very wide perspectives. Concerning the consequences of original sin and the hereditary factors, there prevails in Linnæus an insoluble ambiguity in meaning as well as in words. Apparently fundamental ideas of predestination and determination cannot be sufficiently clarified. In such a twilight his personal religion often becomes very hard to discern. In Biblical terms vengeance was laid in God's hands. But the divine right executed the punishment according to its own primordial law, lex talionis. Among the ancient peoples Nemesis was a daughter of Dike.

Linnæus' thoughts often move in a direction pointing beyond the world of the five senses. Our border-line between Nature and the supernatural is 
blotted out by many of the experiences which Linnæus mentions as his own or those of other people.

The background of the Nemesis speculation is, in its origin, more mystical than religious. Its nuclear mystery is enveloped in the occult philosophy of Linnæus. In Nemesis his theodicy is merely secularized. 